\title{
Impact of Morphine on Viability of MCF-7 and T47D Breast Cancer Cells
}

\author{
Ileana MICLEA ${ }^{1 *}$, Ana-Maria PUI ${ }^{1}$ and Marius ZĂHAN ${ }^{1}$ \\ ${ }^{1}$ Department of Animal Reproduction, University of Agricultural Sciences and Veterinary Medicine, 3-5, \\ Mănăştur Street, 400372, Cluj-Napoca, Romania. \\ *corresponding author: ileana.miclea@usamvcluj.ro
}

Bulletin UASVM Animal Science and Biotechnologies 76(2)/ 2019

Print ISSN 1843-5262; Electronic ISSN 1843-536X

DOI:10.15835/buasvmcn-asb: 0021.19

\begin{abstract}
Morphine, a highly potent analgesic, is prescribed for the treatment of severe pain associated with cancer. Several in vitro and animal studies suggest that morphine is involved both in promoting and inhibiting tumor growth. Our aim was to test the outcome of adding morphine to the culture media of cells from two of the most widely used breast cancer cell lines. MCF-7 and T47D cells were seeded into 96-well microplates and cultured for 24 hours in MEM and RPMI-1640 media respectively. Afterwards, cells were exposed for 24, 48 or 72 hours to media containing morphine at the following concentrations: $0.05,0.075,0.1,0.25,0.5,0.75,1 \mu \mathrm{M}$. Cell viability was assessed by the MTT colorimetric method. After exposure of MCF-7 cells to morphine for 24 and 48 hours, viability was similar to the control while, after 72 hours, this parameter was significantly enhanced at $0.75 \mu \mathrm{M}$ and $1 \mu \mathrm{M}$. Survival of T47D cells in the first 24 hours was significantly $(\mathrm{p}<0.05)$ increased by the presence of $1 \mu \mathrm{M}$ morphine, while an increased exposure time did not improve the outcome. Our results show that morphine can increase viability of breast cancer cells, depending on concentration, exposure time and cell origin.
\end{abstract}

Keywords: cell viability, MCF-7, morphine, T47D

\section{Introduction}

Breast cancer is the most common cancer in women (Miller et al., 2019), death being usually caused by recurrence and metastasis (Ecimovic et al., 2011). One of the most common symptoms of cancer is pain, with $50-80 \%$ of cancer patients experiencing some degree of pain (Tuerxun and Cui, 2018).

Morphine was isolated in the 19th century by Sertürner from opium (Huxtable and Schwarz, 2001), the dried latex of the opium poppy, Papaver somniferum which has been cultivated for over 3000 years (Perea-Sasiaín, 2008). Opioids have a long history as treatment for diarrhea and pain (Zhang et al., 2008). Their potent analgesic and sedative effects make them widely used in clinical practice (Doornebal et al., 2015). Morphine is used to manage pain but also for anesthetic procedures in cancer patients undergoing surgery (Zhang et al., 2018).

The way morphine influences tumors, either by stimulating or inhibiting growth has been under debate, with in vivo and in vitro studies weighing on either side (Tuerxun and Cui, 2018). Retrospective studies reported that patients who received general anesthesia with large amounts of opioids showed more cancer progression or recurrence than patients who received regional anesthesia or a lower amount of opioids (Biki et al., 2008; Exadaktylos et al., 2006; Maher et al., 2014; 
Scavonetto et al., 2014). This caused significant alarm for the use of morphine especially in lung, breast and prostate cancers.

Opioids have been shown to promote angiogenesis and increase breast cancer progression (Bimonte et al., 2015; Gupta et al., 2002), to accelerate the growth of tumour cells and induce metastasis in lung (Wang et al., 2015) and nasopharyngeal tumors (Cao et al., 2016). Morphine can also inhibit immune cell functions and cause immunosuppression (Gach et al., 2011). On the other hand, Kim et al. (2016) found that morphine may suppress progression of several lung cancer cell lines. Additional studies have reported that opioids can inhibit gastric cancer progression in vitro (Qin et al., 2012), may induce apoptosis in colon cancer (Palma et al., 2015; Zhang et al., 2014) and do not enhance breast cancer expansion (Chen et al., 2017; Doornebal et al., 2015).

Studies of morphine effects in breast cancer have often yielded contradictory results (Juneja, 2014), though it has become apparent that it plays a dual role in the regulation of tumors (Tuerxun and Cui, 2018).

Given the conflicting nature of the currently available evidence, our aim was to test the outcome of adding morphine to the culture media of cells from two of the most widely used breast cancer cell lines.

\section{Materials and Methods Materials}

Culture media MEM and RPMI-1640 were acquired from Biochrom (Merck, Darmstadt, Germany). Morphine hydrochloride $(20 \mathrm{mg} / \mathrm{ml}$ ) solution was obtained from Zentiva (Prague, Czech Republic). Human recombinant insulin and the 3-(4,5-dimethylthiazol-2-yl)-2,5-diphenyltetrazolium bromide (MTT) reagent were obtained from Sigma-Aldrich (Taufkirchen, Germany).

\section{Cell lines and cell culture}

Both cell lines were obtained from The Global Bioresource Center (American Type Culture Collection - ATCC). MCF7 cells maintained in MEM supplemented with $0.01 \mathrm{mg} / \mathrm{ml}$ insulin while T47D were cultured in RPMI-1640.

\section{MTT assay for cell viability}

The effects of morphine on cells were assessed by the MTT colorimetric method (Mosmann, 1983). MCF-7 and T47D cells were seeded into 96-well microplates at a density of $3.5-4 \times 10^{3}$ cells/well and kept in their respective media for 24 hours. Morphine hydrochloride was added to the culture medium for each cell type to achive the following final concentrations: $0.05,0.075,0.1,0.25,0.5$, $0.75,1 \mu \mathrm{M}$ and the cells were incubated for 24,48 or 72 hours. At the end of the these intervals cells were washed once with phosphate buffered saline (PBS) which was then replaced with a MTT solution in PBS $(0.5 \mathrm{mg} / \mathrm{ml})$ and incubated for 1 hour. Cells were lysed and formazan particles were solubilized with $150 \mu \mathrm{l}$ dimethyl sulfoxide. The absorbance was read with the HT Synergy microplate plate reader (BioTek Instruments, USA) at $550 \mathrm{~nm}$ and expressed relative to the background absorbance read at $630 \mathrm{~nm}$. Hydrogen peroxide was used as a positive control at a concentration of $100 \mu \mathrm{M}$ and experiments were repeated 3 times. Results from the assay were reported as percentages of an untreated control. One-way ANOVA followed by Tukey multiple comparisons test was performed using Graph Pad Prism version 8.0.0 for Windows (GraphPad Software, San Diego, California USA).

\section{Results and Discussion}

Contradictory effects of morphine on the viability and multiplication of cancer cells have been reported both in vivo and in vitro. In this context we sought to investigate the outcome of its addition to the culture media of breast cancer cell lines MCF7 and T47D. The opioid concentrations were close to those reported in the plasma of cancer patients receiving chronic morphine treatment for pain relief $(0.9-3.4 \mu \mathrm{M})$ (Tegeder et al., 2003) and to the baseline concentration of morphine in cerebrospinal fluid of approximately $0.4 \mu \mathrm{M}$ detected by Smith et al. (1999).

We found that morphine increased the viability of MCF7 cells in a dose dependent manner beyond what was observed for untreated cells (Fig. 1). This effect was visible at 24 hours starting from the lowest concentrations. However, it became statistically significant at 72 hours, particularly for $0.75 \mu \mathrm{M}$ and $1 \mu \mathrm{M}$. On the other hand, morphine seemed to have little effect on cell viability at 48 hours.

In T47D cells low morphine concentrations $(0.05,0.075$ and $0.1 \mu \mathrm{M})$ resulted in percentages similar to the control for all time frames (Fig. 2). However, starting from $0.25 \mu \mathrm{M}$ morphine and an exposure of 24 hours, cell viability reached a 


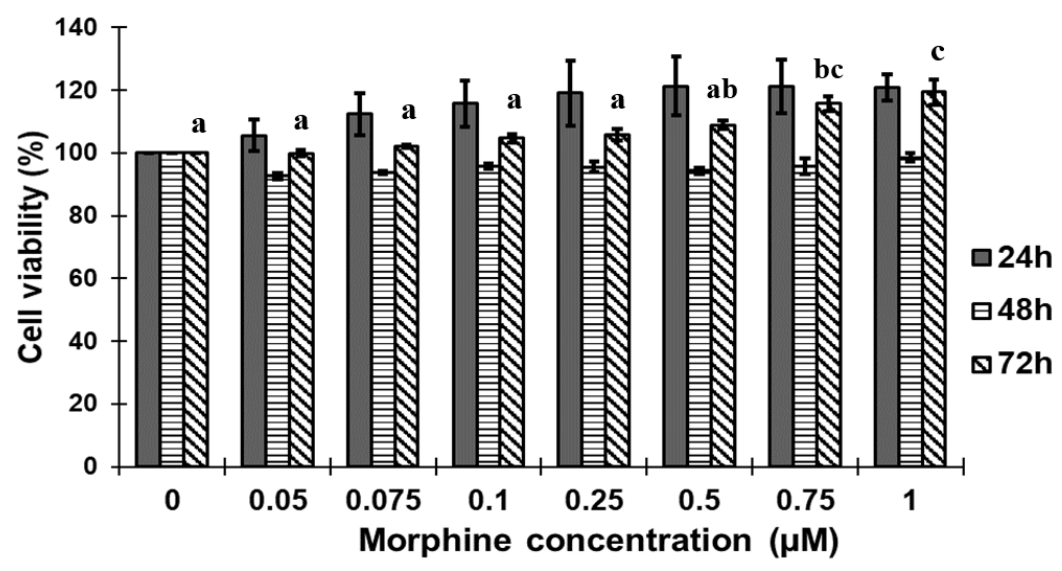

Figure 1. Effect of morphine on MCF7 cells at 24, 48 and 72 hours. Different letters between means from different groups denote significant differences $(\mathrm{p}<0.05)$.

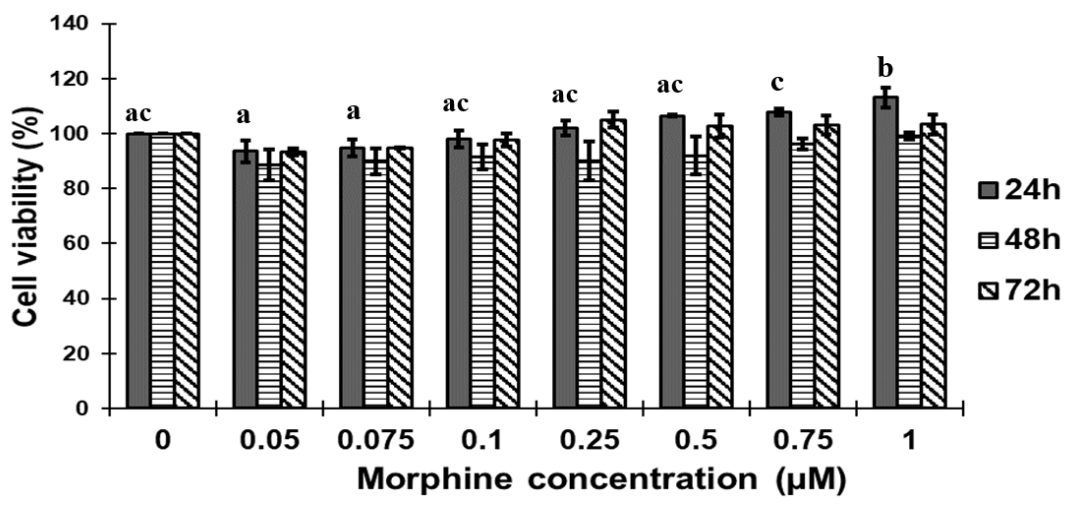

Figure 2. Effect of morphine on T47D cells at 24, 48 and 72 hours. Different letters between means from different groups denote significant differences $(\mathrm{p}<0.05)$.

statistically significant level for $1 \mu \mathrm{M}$. At 72 hours the overall trend was similar but differences between treatments were not so marked. At 48 hours, the situation was comparable to the one observed for MCF7 cells.

The similar situation observed for both cell types at 48 hours could be caused by morphine which may inhibit their growth at this exposure interval before cells can recuperate at 72 hours.

Our results regarding MCF7 cells are similar to those of Ecimovic et al. (2011) who proved that clinical concentrations of morphine directly stimulate migration and proliferation of breast adenocarcinoma cells (MCF7 and MDA-MB-231 cell lines) by increasing expression of the NET1 gene in a mechanism that does not involve opioid receptors. It has also been shown that morphine can induce chemoresistance and promote tumor growth in MCF7 cells (Niu et al., 2015) and that clinically relevant concentrations of morphine can increase breast cancer progression (Bimonte et al., 2015). In vivo this effect would be supported by the proangiogenic activity of morphine found by Gupta et al. (2002).

Hatsukari et al. (2007) found that clinical concentrations of morphine similar to ours induced apoptosis and necrosis in MCF7 cells after a much shorter exposure time of only 4 hours while cytotoxic activity was visible in the mM range. However, the concentrations we employed increased MCF7 proliferation during long exposure such as 72 hours.

In the work of Chen et al. (2017) morphine inhibited cell growth by blocking the cell cycle and promoting apoptosis in MCF-7 cells. Concentrations over $10 \mu \mathrm{M}$ inhibited proliferation of MCF7 cells while concentrations over $0.5 \mathrm{mM}$ caused cell death, via a p53-dependent mechanism (Tegeder et al., 2003). The contrasting effects of morphine observed in diffent studies could result 
from different mechanisms (with or without opioid receptors) or from the combination of dose and exposure time. Interestingly, the work of GonzalezNunez et al. (2014) in the neuroblastoma SH-SY5Y cell line proposes a dual effect of morphine, with low doses $(0.01 \mu \mathrm{M})$ promoting cell proliferation, while higher doses $(1 \mu \mathrm{M})$ would inhibit cell proliferation.

The different effects of morphine in the two cell lines could be ascribed to the presence of different receptors on their surface. These would induce contrasting reactions depending on cell type. Opioid receptors contain three subtypes, $\mu$, $\kappa$, and $\delta$ which modulate a variety of physiological functions such as pain regulation, emotional tone, and cognitive functions (Trescot et al., 2008). They can be found both in neural tissues and extraneural tissues (spleen, stomach, lung, pancreas, liver, heart, blood, and blood vessels) (Chaturvedi et al., 2000).

Hatzoglou et al. (1996) showed that opioids inhibit T47D cell growth, a mechanism mediated through $\kappa$ - and $\delta$-opioid receptors. Their research also showed that T47D cell have no $\mu$-receptors which probably accounts for their different behavior when exposed to morphine. In contrast $\mu$-opioid sites have been identified in MCF7 cells (Maneckjee et al., 1990) and their presence has been shown to promote tumor growth and metastasis (Mathew et al., 2011). This difference in receptors could explain the contrasting responses of the two cell lines, even if both are estrogen receptor-positive.

\section{Conclusion}

Our experiment shows that morphine acts on breast cancer cell viability depending on concentration, exposure time and cell origin, even if both cell lines belong to the same molecular subtype of breast cancer. The mechanism used by opioids to influence cancer cell development is still unclear and more studies should be undertaken to clarify it.

\section{References}

1. Biki B, Mascha E, Moriarty DC, Fitzpatrick JM, Sessler DI, Buggy DJ (2008). Anesthetic technique for radical prostatectomy surgery affects cancer recurrence: a retrospective analysis. Anesthesiology 109, 180-187.

2. Bimonte S, Barbieri A, Rea D, Palma G, Luciano A, Cuomo A, Arra C, Izzo F(2015). Morphine promotes tumor angiogenesis and increases breast cancer progression. Biomed Res Int 2015, 161508.

3. Cao LH, Li HT, Lin WQ, Tan HY, Xie L, Zhong ZJ, Zhou JH (2016). Morphine, a potential antagonist of cisplatin cytotoxicity, inhibits cisplatin-induced apoptosis and suppression of tumor growth in nasopharyngeal carcinoma xenografts. Sci Rep. 6, 8706.

4. Chaturvedi K, Christoffers KH, Singh K, Howells RD (2000). Structure and regulation of opioid receptors. Biopolymers 55(4), 334-346.

5. Chen Y, Qin Y, Li L, Chen J, Zhang X, Xie Y (2017). Morphine can inhibit the growth of breast cancer MCF-7 cells by arresting the cell cycle and inducing apoptosis. Biol Pharm Bull 40(10),1686-1692.

6. Doornebal CW, Vrijland K, Hau CS, Coffelt SB, Ciampricotti M, Jonkers J, de Visser KE, Hollmann MW (2015). Morphine does not facilitate breast cancer progression in two preclinical mouse models for human invasive lobular and HER2 ${ }^{+}$breast cancer. Pain 156(8), 1424-1432.

7. Ecimovic P, Murray D, Doran P, McDonald J, Lambert DG, Buggy DJ (2011). Direct effect of morphine on breast cancer cell function in vitro: role of the NET1 gene. Br J Anaesth 107(6), 916-923.

8. Exadaktylos AK, Buggy DJ, Moriarty DC, Mascha E, Sessler DI (2006). Can anesthetic technique for primary breast cancer surgery affect recurrence or metastasis? Anesthesiology 105, 660-664.

9. Gach K, Wyrębska A, Fichna J, Janecka A (2011). The role of morphine in regulation of cancer cell growth. Naunyn Schmiedebergs Arch Pharmacol 384(3), 221-230.

10. Gonzalez-Nunez V, Noriega-Prieto JA, Rodriguez RE (2014). Morphine modulates cell proliferation through mir133b \& mir128 in the neuroblastoma SH-SY5Y cell line. Biochim Biophys Acta 1842, 566-572.

11. Gupta K, Kshirsagar S, Chang L, Schwartz R, Law PY, Yee D, Hebbel RP (2002). Morphine stimulates angiogenesis by activating proangiogenic and survival-promoting signaling and promotes breast tumor growth. Cancer Res 62(15), 4491-4498.

12. Hatsukari I, Hitosugi N, Ohno R, Hashimoto K, Nakamura S, Satoh K, Nagasaka H, Matsumoto I, Sakagami H (2007). Induction of apoptosis by morphine in human tumor cell lines in vitro. Anticancer Res 27(2), 857-864.

13. Hatzoglou A, Bakogeorgou E, Castanas E (1996). The antiproliferative effect of opioid receptor agonists on the T47D human breast cancer cell line, is partially mediated through opioid receptors. Eur J Pharmacol 296(2), 199207.

14. Huxtable RJ, Schwarz SK (2001). The isolation of morphine-first principles in science and ethics. Mol Interv 1, 189-191.

15. Juneja R (2014). Opioids and cancer recurrence. Curr Opin Support Palliat Care 8, 91-101.

16. Kim JY, Ahn HJ, Kim JK, Kim J, Lee SH, Chae HB (2016). Morphine suppresses lung cancer cell proliferation through the interaction with opioid growth factor receptor: an in vitro and human lung tissue study. Anesth Analg 123(6), 1429-1436. 
17. Maher DP, Wong W, White PF, McKenna RJr, Rosner H, Shamloo B, Louy C, Wender R, Yumul R, Zhang $V$ (2014). Association of increased postoperative opioid administration with non-small-cell lung cancer recurrence: a retrospective analysis. $\mathrm{Br} \mathrm{J}$ Anaesth 113(Suppl 1), i88-94.

18. Maneckjee R, Biswas R, Vonderhaar BK (1990). Binding of opioids to human MCF-7 breast cancer cells, and their effects on growth. Cancer Res 50(8), 2234-2238.

19. Mathew B, Lennon FE, Siegler J, Mirzapoiazova T, Mambetsariev N, Sammani S, Gerhold LM, LaRiviere PJ, Chen CT, Garcia JG, Salgia R, Moss J, Singleton PA (2011) The novel role of the mu opioid receptor in lung cancer progression: a laboratory investigation. Anesth Analg 112(3), 558-567.

20. Miller KD, Nogueira L, Mariotto AB, Rowland JH, Yabroff KR, Alfano CM, Jemal A, Kramer JL, Siegel RL (2019). Cancer treatment and survivorship statistics, 2019. CA Cancer J Clin doi:10.3322/caac.21565.

21. Mosmann T (1983). Rapid colorimetric assay for cellular growth and survival: application to proliferation and cytotoxicity assays. J Immunol Methods 65(1-2), 55-63.

22. Niu DG, Peng F, Zhang W, Guan Z, Zhao HD, Li JL, Wang KL, Li TT, Zhang Y, Zheng FM, Xu F, Han QN, Gao P, Wen QP, Liu Q (2015). Morphine promotes cancer stem cell properties, contributing to chemoresistance in breast cancer. Oncotarget 6(6), 3963-3976.

23. Palma G, Luciano A, Cuomo A, Arra C, Izzo F, Zhang XL, Chen ML, Zhou SL (2015). Fentanyl inhibits proliferation and invasion of colorectal cancer via beta-catenin. Biomed Res Int 8(1), 227-235.

24. Perea-Sasiaín J (2008). Biosynthesis of morphine: its importance in Parkinson's disease. Rev Fac Med 56, 161189.

25. Qin Y, Chen J, Li L, Liao CJ, Liang YB, Guan EJ, Xie YB (2012). Exogenous morphine inhibits human gastric cancer MGC- 803 cell growth by cell cycle arrest and apoptosis induction. Asian Pac J Cancer Prev 13(4), 1377-1382.
26. Scavonetto F, Yeoh TY, Umbreit EC, Weingarten TN, Gettman MT, Frank I, Boorjian SA, Karnes RJ, Schroeder DR, Rangel LJ, Hanson AC, Hofer RE, Sessler DI, Sprung J (2014). Association between neuraxial analgesia, cancer progression, and mortality after radical prostatectomy: a large, retrospective matched cohort study. Br J Anaesth 113(Suppl 1), i95-102.

27. Smith MT, Wright AW, Williams BE, Stuart G, Cramond T (1999). Cerebospinal fluid and plasma concentrations of morphine, morphine-3-glucronide, and morphine6-glucronide in patients before and after initiation of intracerebroventricular morphine for cancer management. Anesth Analg 88(1), 109-116.

28. Tegeder I, Grosch S, Schmidtko A, Haussler A, Schmidt H, Niederberger E, Scholich K, Geisslinger G (2003). G proteinindependent $\mathrm{G}(1)$ cell cycle block and apoptosis with morphine in adenocarcinoma cells: involvement of p53 phosphorylation. Cancer Res 63(8), 1846-1852.

29. Trescot AM, Datta S, Lee M, Hansen H (2008). Opioid pharmacology. Pain physician 11(2 Suppl), S133-153.

30. Tuerxun H, Cui J (2019). The dual effect of morphine on tumor development. Clin Transl Oncol 21(6), 695-701.

31. Wang K, Qu X, Wang Y, Shen H, Liu Q, Du J (2015). Effect of mu agonists on long-term survival and recurrence in nonsmall cell lung cancer patients. Medicine 94(33):e1333.

32. Zhang XL, Chen ML, Zhou SL (2014). Fentanyl increases colorectal carcinoma cell apoptosis by inhibition of NFkappaB in a Sirt1-dependent manner. Asian Pac J Cancer Prev 15(22), 10015-10020.

33. Zhang XY, Liang YX, Yan Y, Dai Z, Chu HC (2018). Morphine: double-faced roles in the regulation of tumor development. Clin Transl Oncol 20(7), 808-814.

34. Zhang Y, Chen Q Yu LC (2008). Morphine: a protective or destructive role in neurons? Neuroscientist 14(6), 561570 . 